\title{
Piotr Skonieczny
}

Pojęcie dobrego imienia (bona fama) w Kodeksie Prawa Kanonicznego z 1983 r. Jana Pawła II na podstawie kan. 220

Prawo Kanoniczne : kwartalnik prawno-historyczny 52/1-2, 59-84

2009

Artykuł został opracowany do udostępnienia w internecie przez Muzeum Historii Polski w ramach prac podejmowanych na rzecz zapewnienia otwartego, powszechnego i trwałego dostępu do polskiego dorobku naukowego i kulturalnego. Artykuł jest umieszczony w kolekcji cyfrowej bazhum.muzhp.pl, gromadzącej zawartość polskich czasopism humanistycznych i społecznych.

Tekst jest udostępniony do wykorzystania w ramach dozwolonego użytku. 


\section{O. PIOTR SKONIECZNY OP}

\section{POJECIE DOBREGO IMIENIA (BONA FAMA) W KODEKSIE PRAWA KANONICZNEGO Z 1983 R. JANA PAWŁA II NA PODSTAWIE KAN. 220}

Treść: Wstęp. - 1. Przepisy dotyczące dobrego imienia w Kodeksie Prawa Kanonicznego z 1983 r. - 2. Verba legis z części pierwszej kan. 220: bona fama. - 2.1. Słowa na określenie dobrego imienia w verba legis Kodeksu Jana Pawła II z 1983 r. - 2.2. Bona fama, bona exsistimatio i infamia w ujęciu historycznym. - 2.3. Historia powstania przepisu części pierwszej kan. 220. - 3. Zakres przedmiotowy pojęcia dobrego imienia w części pierwszej kan. 220. - 3.1. Ochrona czci w ustawodawstwach świeckich na przykładzie prawa polskiego. - 3.2. Zakres przedmiotowy ochrony dobrego imienia (bona fama) z kan. 220. - 3.3. Zakres przedmiotowy ochrony dobrego imienia w innych przepisach KPK. - Zakończenie.

\section{Wstęp}

Niejednokrotnie do pojęcia dobrego imienia odwołują się obecnie niemal wszyscy, którzy się zmagają z problemem lustracji. Pojęcie dobrego imienia pojawia się też w dokumentach Kościoła w Polsce, wydanych w związku z lustracją duchowieństwa ${ }^{1}$.

${ }^{1}$ Odwołanie do pojęcia dobrego imienia następuje bądź wprost, bądź pośrednio. Wprost pojęcia dobrego imienia dotyczy na przykład dokument K o m i s j i Te o 1 o giczno-Duszpasterskiej „Pamięć i Troska” Archidiecez j i K r a k ow s k i e j z dnia 4 lipca 2007 r. pt.: Prawda i odpowiedzialność. Elementarne zasady teologiczno-duszpasterskie, dotyczace przekazywania i odbioru informacji o wspótpracy niektórych osób ze stużbami reżimu komunistycznego w okresie PRL zob. http://www.episkopat.pl/?a=dokumentyKEP\&doc=200775_1 (Dostęp: 2007.09.14). Dokument ten w całości niemal jest poświęcony zagadnieniu ochrony dobrego imienia (por. zwłaszcza n. 2, 4 i 6), aczkolwiek nie zajmuje się tym zagadnieniem od strony prawniczej. Natomiast pośrednio - poprzez nawiązanie do obmowy lub oszczerstwa (n. 3) - zagadnienia ochrony dobrego imienia dotyczy Memoriat Episkopatu Polski $w$ sprawie wspótpracy niektórych duchownych z organami bezpieczeństwa $w$ Polsce $w$ latach 1944-1989, wydany przez biskupów diecezjalnych dnia 25 sierpnia 2006 r., zob. 
Pojęciem dobrego imienia (bona fama) posługuje się jednak przede wszystkim Kodeks Prawa Kanonicznego z 1983 r. Jana Pawła II, zwłaszcza w przepisie części pierwszej kan. 220. Warto zatem rozważyć, co ustawodawca w kodeksie rozumiał przez pojęcie bona fama, tym bardziej, że zagadnienie ochrony dobrego imienia nabiera coraz większego znaczenia w życiu Kościoła, nie tylko w Polsce.

\section{Przepisy dotyczące dobrego imienia w Kodeksie Prawa Kanonicznego z 1983 r.}

Dobre imię (dobra sława, cześć) należy do tzw. dóbr osobistych człowieka ${ }^{2}$. Jest to powszechny szacunek, przysługujący każdemu na podstawie jego naturalnej godności ${ }^{3}$. Systemy prawne - czy to świeckie, czy też system prawa kanonicznego - chronią dobre imię człowieka. Zazwyczaj regulacja prawna jest bardzo lakoniczna ${ }^{4}$.

Nic więc dziwnego, że - wzorem nowoczesnych kodyfikacji cywilnych europejskich (jak np. niemieckiej, francuskiej, austriackiej czy polskiej ${ }^{5}$ ) - również Kodeks Prawa Kanonicznego Jana Pawła II

http://www.episkopat.pl/?a = dokumentyKEP\&doc $=2006825$ _0 (Dostęp: 2007-09-14). Ponadto do zagadnienia ochrony dobrego imienia wprost odnosi się Stowo biskupów polskich do wszystkich wiernych Kościoła w Polsce, n. 5, odczytane dnia 14 stycznia 2007 r. w związku ze sprawą ks. abp. Stanisława Wielgusa, Wiadomości Kai z dnia 21 stycznia 2007, nr 3 (772), s. 10. Również ostatnio w literaturze przedmiotu - co prawda nie przy okazji lustracji duchowieństwa Kościoła w Polsce - pojawił się problem dobrego imienia; por. A. B r z e m i a - B o n a r e k, Dopuszczalność dowodów zdobytych w sposób niegodziwy w kanonicznym procesie o stwierdzenie nieważności malżeństwa, Katowice 2007, zwłaszcza s. 63, 76-82, 92-94, 107-133. Natomiast wprost problemu na tle lustracji duchownych w Polsce dotyczy tekst: J. Krukowski, Zasady relacji Państwo - Kościót a >lustracja < osób duchownych w Polsce, „Niedziela” z dnia 18 marca 2007 r., nr 11, s. 14-17.

${ }^{2}$ Prócz dobrego imienia do tych dóbr osobistych należą w szczególności zdrowie, wolność, swoboda sumienia, nazwisko lub pseudonim, wizerunek, tajemnica korespondencji, nietykalność mieszkania, prywatność itd. Por. w szczególności art. 23 kodeksu cywilnego (cyt. dalej w skrócie k.c.) i orzecznictwo, które na przykład można znaleźć w: M. R o z w a d o w s k a - H e r r m a n n, Kodeks cywilny. Edycja 2004, Warszawa 2004, s. 23-25, tezy do art. 23.

${ }^{3}$ T. P a w 1 u k, Prawo kanoniczne wedlug Kodeksu Jana Pawła II, t. II: Lud Boży, jego nauczanie i uświęcanie, Olsztyn 2002, s. 42.

${ }^{4}$ Zob. A. S z p u n a r, Ochrona dóbr osobistych, Warszawa 1979, s. 15, 17. W kodeksie cywilnym tematyki tej dotyczą tylko przepisy art. 23,24 i art. $43 \mathrm{w}$ zw. $\mathrm{z}$ art. 23 i 24 .

${ }^{5}$ Por. A. S z p u n a r, Ochrona..., s. 17-77. Gwoli ścisłości w niemieckim systemie prawa cywilnego tzw. ogólne prawo osobowości (allgemeine Persönlichkeitsrecht) wywiedziono z art. 1 i 2 niemieckiej Ustawy Zasadniczej; zob. H. B r o x, Allgemeiner 
reguluje ochronę dobrego imienia jedynie w kilku przepisach, przy czym w zasadzie jeden tylko przepis stanowi podstawę do konstruowania normy prawnokanonicznej. Problematyki tej bowiem dotyczy kan. 220 i jest to w zasadzie przepis podstawowy. Przepis kan. 220 stanowi: Nemini licet bonam famam, qua quis gaudet, illegitime laedere, nec ius cuiusque personae ad propriam intimitatem tuendam violare. Kanon ten został przetłumaczony następująco: Nikomu nie wolno bezprawnie naruszać dobrego imienia, które ktoś posiada, ani też naruszać prawa każdej osoby do ochrony własnej intymności. Do kanonu tego odsyła ponadto przepis kan. 642 części drugiej, stanowiący, że stwierdzenie przymiotów kandydatów do nowicjatu następuje również przy pomocy biegłych z zachowaniem przepisu kan. 220.

Pojęciem bona fama posługują się ponadto inne przepisy KPK, jednakże nie stanowią one wprost ochrony dobrego imienia, jak ma to miejsce na gruncie przepisu części pierwszej kan. 220. Te przepisy KPK mają znaczenie dla ochrony dobrego imienia, chociaż dyspozycji normy prawnej nie wyrażają tak wyraźnie, jak kan. 220. Do przepisów tych należą kanony: 378 § 1 n. 2, 483 § 2, 1029, 1048,

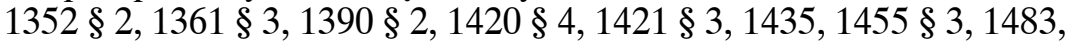
$1548 \S 2$ n. $2,1717 \S 2$ oraz kan. 1741 n. $3^{6}$.

Ponadto ochronę dobrego imienia w sensie szerszym dostrzega się w przepisach kanonów: 51, 699 § 1, 1611 n. 3, 1742 § 1, 1745 itp. (uzasadnienie dekretów); 700, $1727 \S 1$ (prawo do rekursu albo apelacji); 697 n. 2, $695 \S 2,1720$ n. 2 itp. (pełna możliwość obrony przed zarzutami wysuwanymi formalnie) $)^{7}$.

W doktrynie prawa kanonicznego podjęto próbę usystematyzowania tej długiej listy przepisów w Kodeksie Jana Pawła II, chroniących dobre imię wiernych bądź w jakikolwiek sposób odnoszą-

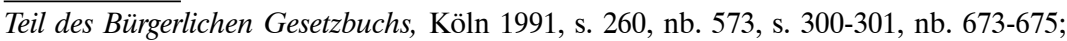
J. L i m b a c h, „Promieniowanie” konstytucji na prawo prywatne, Kwartalnik Prawa Prywatnego 8 (1999) nr 3, s. 405-406.

${ }^{6}$ Zob. Codex Iuris Canonici auctoritate Ioannis Pauli PP. II promulgatus. Fontium annotatione et indice analytico-alphabetico auctus, red. $\mathrm{P}$ o $\mathrm{n} \mathrm{t}$ i $\mathrm{f}$ i c i a $\mathrm{C} \mathrm{o} \mathrm{m} \mathrm{m} \mathrm{is} \mathrm{s} \mathrm{i} \mathrm{o}$ Codici I uris Canonici Authentice Interpretando, Città del Vaticano 1989, s. 580, hasło: fama. Niepełny wykaz kanonów posługujących się pojęciem bona fama zob. A. Benlloch Poveda (red.), Código de derecho canónico. Edición bilingüe, fuentes y comentarios de todos los cánones, Valencia 1993, s. 766, hasło: fama.

${ }^{7}$ Tak L. C h i a p p e t t a, Il Codice di Diritto Canonico. Commento giuridico-pastorale, t. I, Roma 1996, tezy do kan. 220, nb. 1377-1378, s. 316. 
cych się do dobrego imienia ${ }^{8}$. Można zatem wyróżnić trzy grupy przepisów.

Pierwsza grupa to przepisy wprowadzające wymóg dobrego imienia dla otrzymania urzędu w Kościele (kan. 378 § 1 n. 2, 1029, $483 \S 2,1420$ § $4,1421 \S 3,1435,1483,1741$ n. 3).

Drugą grupę $\mathrm{z}$ kolei stanowią przepisy wprost chroniące dobre imię (kan. 1048, 1352 § 2, 1361 § 3, 1455 § 3, 1548 § 2 n. 2 i $1717 \S 2)^{9}$.

${ }^{8}$ Por. A. P e r e g o, La buona fama nella vita ecclesiale e la sua protezione nell'ordinamento canonico, Roma 2003, s. 77-88.

${ }^{9}$ Ciekawe, że w tej grupie przepisów, chroniących wprost dobre imię, nie został wymieniony kan. 220; zob. A. P e r e g o, La buona fama..., s. 82-88; jakkolwiek Autor w innym miejscu wskazuje wprost na znaczenie kan. 220 dla ochrony dobrego imienia w systemie prawa kanonicznego, a także zwraca uwagę na charakter normatywny tego przepisu; por. tamże, s. 94, 97. Z poglądem tym trzeba się zgodzić. Co prawda, z kan. 220 nie wynika sankcja normy prawnej. Jednakże na podstawie wymienionych wyżej w tekście przepisów KPK, chroniących dobre imię, na czele z częścią pierwszą kan. 220, można zbudować normę prawną. Dyspozycja tej normy zakazuje naruszania dobrego imienia człowieka, hipoteza wyznacza zakres i warunki tejże ochrony prawnej, sankcja zaś wynika z całego systemu prawa kanonicznego. (Nawet mając świadomość specyfiki norm kanonicznych, a zwłaszcza częstego braku sankcji, na co zwraca uwagę: R. S o b a ń s k i, Nauki podstawowe prawa kanonicznego, t. 1: Teoria prawa kanonicznego, Warszawa 2001, s. 73; t e n ż e, Kościót - prawo - zbawienie, Katowice 1979, s. 275). A zatem trzeba by zająć inne stanowisko odnośnie do zagadnienia przepis prawny - norma prawna niż na przykład prezentowane przez R. S o b a ń s k i e g o [w:] J. K r u k o w s k i, R. S o b a ń s k i, Komentarz do Kodeksu Prawa Kanonicznego, t. I: Księga I. Normy ogól$n e$, red. J. K r u k o w s k i, Pallotinum [Poznań] 2003, s. 44, aczkolwiek inaczej u tegoż Autora wcześniej w: R. S o b a ń s k i, Teoria prawa kościelnego, Warszawa 1992, s. 159 (zwłaszcza pkt 3). Norma prawna bowiem to nakaz powinnego zachowania się, skonstruowany z przepisów prawa, według określonej struktury. Por. przedstawienie problemu u: R. S o b a ń s k i, Z zagadnień normy kanonicznej, PK 33 (1990) nr 1-2, s. 3-20; t e n ż e, Teoria..., zwłaszcza s. 140-159; t e n ż e, Nauki..., t. I, s. 52-55. O różnych możliwościach rozwiązania tego problemu por.: R. S o b a ń s k i, Teoria..., s. 142-145; t e n ż e, Nauki..., t. I, s. 69-70. Bardziej od strony materialnoprawnej, a nie teoretycznoprawnej, ze szczególnym uwzględnieniem zagadnień specyfiki normy kanonicznej (zwłaszcza jej „komponentów”: eklezjologicznego, moralnoteologicznego i osobowego - s. 29-31) w porównaniu z normą prawną w teorii prawa cywilnego - por. H. P r e e, Bemerkungen zum Normenbegriff des CIC/1983, ÖAfKR 35 (1985) nr 1/2, s. 25-61. Zob. też M. Z i e 1 i ń s k i, Wykładnia prawa. Zasady, reguły, wskazówki, Warszawa 2002, s. 31-34. Problem relacji przepis prawny - norma prawna na gruncie kan. 220 przekracza jednak ramy niniejszego opracowania.

W literaturze przedmiotu, dotyczącej przepisu części pierwszej kan. 220, zaprezentowano pogląd, jak na razie odosobniony, o normatywnym charakterze tego przepisu, twierdząc, że w przepisie tym zawarte są „dwie normy, komplementarnie powiązane”. Tymi normami miałyby być: po pierwsze, norma uznająca, że każdy człowiek ma prawo do zachowania dobrej opinii, jaką się cieszy w społeczeństwie; po drugie zaś, norma zakazująca nielegalnego naruszania czyjegokolwiek prawa do dobrej opinii; por. 
Trzecia grupa w końcu to przepisy chroniące dobre imię nie wprost. Ta ochrona nie wprost może dokonywać się na dwa sposoby - bądź w postępowaniu sądowym czy administracyjnym, bądź przez tajemnicę spowiedzi (sigillum sacramentale), sekret czy tajemnicę zawodową (secretum). W postępowaniu sądowym czy administracyjnym dobre imię może być chronione na trzy sposoby, tj.: przez obowiązek uzasadnienia (kan. 51, 699 § 1, 1611 n. 3, 1617, $1668 \S 3,1742 \S 1,1745$ n. 3), przez prawo wiernego do rekursu lub apelacji (kan. 700, 1628, 1727 \$1, 1737 § 1) i przez obronę wiernego wobec formalnie przedstawionych zarzutów (kan. $695 \S 2,697 \mathrm{n}$. 2, $1598 \S 1,1720$ n. 1, 1725). Z kolei przez tajemnicę spowiedzi, sekret czy tajemnicę zawodową chronią dobre imię następujące przepisy: kan. $983 \S 1,1388 \S 1,1550 \S 2$ n. 2 (sigillum sacramentale) ${ }^{10}$; $127 \S 3,471$ n. 2,983 § 2, 1388 § 2, 1131 n. 2, 1455 § 1-2, 1457 § 1, 1548 \& 2 n. 1 (secretum).

Jak zatem widać, ochrona dobrego imienia przewidziana jest przez szereg przepisów Kodeksu Jana Pawła II. Wśród nich rolę zasadniczą zajmuje część pierwsza kan. 220.

\section{Verba legis z części pierwszej kan. 220: bona fama}

\subsection{Stowa na określenie dobrego imienia $w$ verba legis Kodeksu Jana Pawta II z 1983 r.}

Żaden też z systemów prawnych nie podaje definicji dobrego imienia, czci lub dobrej sławy. W tym zakresie ustawodawca, także kościelny, odsyła do potocznego rozumienia pojęcia.

W Kodeksie Prawa Kanonicznego z 1983 r. ustawodawca posługuje się terminem bona fama (kan. 220, 1390 § 2, 1483), które tłumaczone jest jako dobre imię ${ }^{11}$. Związkiem frazeologicznym

J. K r u k o w s k i, Prawa wiernych do dobrej opinii i do własnej intymności. Komentarz do kan. $220 \mathrm{KPKz} 1983$ r., PK 39 (1996) nr 3-4, s. 231.

${ }^{10}$ Również zob. K o n g r e g a c j a $\mathrm{N}$ a u k i W i a r y, Dekret z dnia 23 września 1988 r. o ekskomunice, której podlegają ujawniający treść spowiedzi Congregatio, AAS 80 (1988), s. 1367; przekł. polski: W trosce o petnię wiary. Dokumenty Kongregacji Nauki Wiary 1966-1994, przekł. i opr. Z. Z i m o w s k i, J. K r ó l i k o w s k i, Tarnów 1995, s. 324. Por. też J. S y r y j c z y k, Kanoniczne prawo karne: część szczególna, Warszawa 2003, s. 133-134.

${ }^{11}$ Por. Kodeks Prawa Kanonicznego. Przekład polski zatwierdzony przez Konferencję Episkopatu, Poznań 1984; z wyjątkiem wszakże kan. 1483, w którym bona fama jest tłumaczone jako nienaruszona sława. Wydaje się, że tłumaczenie to jest nie najlep- 
bliskoznacznym jest famae integrae esse (kan. $483 \S 2,1420 \S 4$, $1421 \S 3,1435)$, tłumaczone w oficjalnym polskim przekładzie CIC na różne sposoby, tj.: mieć nieposzlakowana opinię (kan. 483 §), być nienaruszonej stawy (kan. 1420 § 4, 1421 § 3), być dobrego imienia (kan. 1435). Słowo fama występuje także bez żadnych oznaczeń przymiotnikowych w CIC, np.: w kan. $1361 \S 3$ (famam tuere, przethumaczone jako chronić dobre imię), kan. 1455 § 3 (stawa), kan. 1572 n. 2 (pogłoska) i kan. 1707 § 2 (rozgłos) ${ }^{12}$.

Słowem bliskoznacznym do fama jest exsistimatio (bona exsistimatio, czyli dobra opinia) w kan. 378 \& $1 \mathrm{n} .2$ oraz słowo existimatio (bona existimatio - w kan. 1029 thumaczone jako dobra opinia, natomiast w kan. 1741 n. 3 jako dobre imię; z kolei w kan. 1554 ma to słowo inne zupełnie znaczenie uznania, opinii sędziego $)^{13}$. W koncu trzeba też zwrócić uwagę na słowo infamia, którym posługuje się ustawodawca kościelny w kan. 1048, 1352 § i 1548 § n. 2, a które thumaczone jest polskim zniestawienie ${ }^{14}$.

2.2. Bona fama, bona exsistimatio $i$ infamia $w$ ujęciu historycznym

Charakterystyczne jest, że ustawodawca w części pierwszej kan. 220 unika pojęcia bona existimatio. Wydaje się, że słusznie, biorąc pod uwagę pochodzenie i znaczenie tego łacińskiego słowa.

W późnym prawie rzymskim, zwłaszcza w definicji czci u Callistratusa $^{15}$, posługiwano się właśnie słowem existimatio. Według tej definicji cześć (existimatio) ${ }^{16}$ była pojęciem prawniczym (ein rein ju-

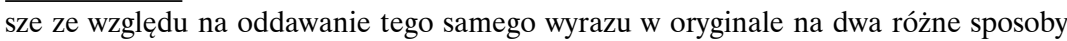
w przekładzie. Z kolei J. K r u k o w s k i, Katalog podstawowych obowiązów i uprawnień wszystkich chrześcijan w nowym Kodeksie Prawa Kanonicznego, RTK 31 (1984) nr 5, s. 50-51 - proponuje thumaczenie dobra opinia.

${ }^{12} \mathrm{~W}$ tym przypadku tłumaczenie jednego terminu różnymi odpowiednikami polskimi było podyktowane różnorodnością znaczeniową łacińskiego słowa fama; por. J. S o n d e 1, Słownik łacińsko-polski dla prawników i historyków, Kraków 2001, s. 373, hasło: fama; K. K u m a n i e c k i, Stownik łacińsko-polski, Warszawa 1988, s. 207, hasło: fama; A. J o u g a n, Słownik kościelny łacińsko-polski, Poznań 1958, s. 253, hasło: fama.

${ }^{13}$ Zob. J. S o n d e 1, Stownik..., s. 354, hasło: existimatio; A. J o u g a n, Stownik... , s. 241, hasło: existimatio.

${ }^{14}$ Por. J. S o n d e 1, Stownik..., s. 480, hasło: infamia; A. J o u g a n, Stownik... s. 335, hasło: infamia.

${ }^{15}$ Por. A. M ü h 1 e b a c h, Die Infamie in der decretalen Gesetzgebung, Paderborn 1923, s. 16-17.

${ }^{16}$ Existimatio est dignitatis inlaesae status, legibus ac moribus comprobatus, qui ex 
ristischer Begriff ${ }^{17}$, rein positiv $\left.{ }^{18}\right)$, przysługiwała bowiem jedynie obywatelowi rzymskiemu (civis Romanus). Jedynie więc ten, kto cieszył się trojakim satus: libertatis, civitatis oraz familiae - mógł też cieszyć się existimatio. Utrata choćby jednego ze status oznaczała utratę existimatio, choć nie utratę dignitas (ogólnej godności ludzkiej, właściwej wszystkim ludziom). Ani zatem obcy ${ }^{19}$, ani niewolnicy, nawet jeżeli cieszyli się dobrą sławą u bliźnich, nie posiadali existimatio. Nie oznacza to wszelako, że czci odmawiano niewolnikom czy obcym, ale nie nazywano jej existimatio, a jedynie dignitas ${ }^{20}$.

Ta definicja existimatio nie mogła przyjąć się w Kościele, jako że prawo kościelne nie czyni różnicy ze względu na narodowość, status czy płeć (por. np. Ga 3, 28). Godność chrześcijanina opiera się na tym, że: Christianus sum - i o tym dawali świadectwo męczennicy. Poza tym rzymska existimatio nie miała wydźwięku obyczajowego, moralnego, społecznego, czy ktoś cieszy się dobrą sławą u bliźnich czy też nie. Ponadto edyktem pretorskim existimatio mogła być obywatelowi rzymskiemu odjęta ${ }^{21}$.

W rezultacie formalnoprawne rozumienie existimatio spowodowało, że zaczęto w prawie rzymskim odróżniać infamia iuris i infamia facti ${ }^{22}$.

Pojęcie rzymskie infamii musiało zostać zmodyfikowane przez prawo kościelne pod wpływem prawa germańskiego, które nie pod-

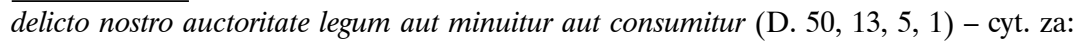
A. M ü h 1 e b a c h, Die Infamie..., s. 18 z przyp. 1.

${ }^{17}$ Por. B. L ö b m a n n, Der kanonische Infamiebegriff in seiner geschichtlichen Entwicklung. Unter besonderer Berücksichtigung der Infamielehre des Franz Suarez, Leipzig 1956 , s. 30.

${ }^{18}$ Tak z kolei A. M ü h 1 e b a c h, Die Infamie..., s. 19.

${ }^{19}$ Instytucja existimatio była iuris civilis, a nie iuris gentium; por. A. M ü h 1 e b a c h, Die Infamie..., s. 19.

${ }^{20}$ Zob. A. M ü h 1 e b a c h, Die Infamie..., s. 18 z przyp. 3; B. L ö b m a n n, Der kanonische Infamiebegriff..., s. 28-30.

${ }^{21}$ Por. A. M ü h 1 e b a c h, Die Infamie..., s. 18-20.

${ }^{22}$ Infamia iuris mogła być bądź infamia immediata, która powstawała z mocy samego prawa (na przykład m. in. wskutek dezercji, bigamii, upadłości, uprawiania zawodu aktora, stręczycielstwa), bądź infamia mediata, którą się zaciągało wskutek wyroku sądowego (skazanie na kary cielesne, wolnościowe czy pozbawienie życia, a potem także wyroki cywilne z tytułu tzw. actiones famosae). Z infamia iuris związane były skutki ustawowe (np. pozbawienie zdolności prawnej, zdolności reprezentowania kogoś przed organami ochrony prawnej, prawa wyborczego i praw honorowych). Natomiast z infamia facti powstają skutki naturalne, które też mogą być przewidziane przez ustawę. Zob. B. L ö b m a n n, Der kanonische Infamiebegriff..., s. 136; A. M ü h l e b a c h, Die Infamie..., s. 20-22, gdzie też dokładniejszy opis instytucji. 
chodziło do infamii w sposób formalny, prawny. Godność w prawie germańskim przyznawano każdemu; z kolei dobre imię miało znaczenie moralne (np. w Sachsenspiegel) ${ }^{23}$. Stąd katalogi infames w prawie kościelnym powiększone zostały o przypadki przewidziane w prawie germańskim, tj. choćby: zdrajcy, przechodzacy na stronę wroga, łamiący ślub czystości, zrodzeni z nieprawego łoża ${ }^{24}$.

Nic więc dziwnego, że na gruncie prawa kanonicznego należało sięgnąć do pojęcia moralnoteologicznego czy socjologicznego dobrego imienia - fama, a nie prawnego czy prawniczego - existimatio. Właśnie na pojęciu fama bazuje prawo kanoniczne. Fama jest dobrym imieniem, którym ktoś się cieszy w oczach swoich bliźnich; infamia natomiast jest utrata tego dobrego imienia ${ }^{25}$. Infamia bowiem była instytucją prawną i zaciągnięcie jej powodowało określone skutki prawne, jak choćby: popadnięcie w nieregularność, utrata dignitates et honores (ubioru, beneficjów z tym związanych), a także niemożliwość podejmowania actus legitimi, tj. bycia świadkiem, prawa skargi, sporządzania testamentu, piastowania pewnych urzędów (np. sędziego, adwokata itd.) ${ }^{26}$. Regulacja infamii niemal w całości została przejęta przez CIC z 1917 r. (kan. 2293-2295) ${ }^{27}$.

Trzeba zatem odróżnić fama od infamia. O ile na kształtowanie się fama prawo rzymskie raczej nie miało wpływu i została ona dostrzeżona właściwie dopiero w XX wieku, a w zasadzie w trakcie powstawania Kodeksu Jana Pawła II, o tyle instytucja infamii w znacznej mierze przejęło szereg elementów obcych ${ }^{28}$. Słuszne jest również rozwiązanie, w którym ustawodawca zrezygnował z jurydycznego ujęcia existimatio. Niepotrzebnie jednak pojęcie to pojawia się w niektórych przepisach kodeksu, wprowadzając zamieszanie pojęciowe.

2.3. Historia powstania przepisu części pierwszej kan. 220

Historia treści przepisu części pierwszej kan. 220 nie jest dłu$\mathrm{ga}^{29}$. O wiele dłuższa jest niejako ,prehistoria” w ogóle ochrony

${ }^{23}$ Zob. A. M ü h 1 e b a c h, Die Infamie..., s. 33.

${ }^{24}$ Por. tamże, s. 27-31.

${ }^{25}$ Zob. B. L ö b m a n n, Der kanonische Infamiebegriff..., s. 30, 135.

${ }^{26}$ Zob. A. M ü h 1 e b a c h, Die Infamie..., s. 83, 86-99.

${ }^{27}$ Por. F. B ą c z k o w i c z C M, Prawo kanoniczne. Podręcznik dla duchowieństwa, t. III, Opole 1958, s. 466-468, n. 508.

${ }^{28}$ Por. B. L ö b m a n n, Der kanonische Infamiebegriff..., s. 133.

${ }^{29}$ Bardzo krótko traktuje ją A. P e r e g o, La buona fama..., s. 94-97. 
dobrego imienia w prawie kanonicznym ${ }^{30}$, obejmując historię szeregu szczegółowych instytucji prawa kanonicznego, jak na przykład przeszkód do święceń czy infamii, czy w końcu przestępstwa zniesławienia, o którym stanowił kan. 2355 CIC z $1917 \mathrm{r}^{31}$. Nie jest jednak przedmiotem niniejszych rozważań dokonanie szczegółowej analizy historycznej tych instytucji prawa kanonicznego ${ }^{32}$. Bogate są także źródła teologiczne tego przepisu ${ }^{33}$. Nie można też zapominać, że część pierwsza kan. 220 ma również swoje korzenie w prawie międzynarodowym ${ }^{34}$, a zwłaszcza

${ }^{30}$ Stąd nie można bez zastrzeżeń zgodzić się z poglądem J. H e r v a d a, Diritto constituzionale canonico, Milano 1989, s. 139, że dobre imię zyskało wyraźną ochronę sądową w prawie kanonicznym dopiero z chwilą wejścia w życie Kodeksu Jana Pawła II. Wydaje się, że jest to znaczne uproszczenie zagadnienia. Ochronę tę bowiem prawo kanoniczne zapewniało pośrednio za pomocą szeregu instytucji szczególnych. Trzeba jednak przyznać, że tak ogólna norma chroniąca dobre imię - i to na forum sądowym, wziąwszy pod uwagę treść kan. 221 - jest zupełną nowością w ustawodawstwie kościelnym.

${ }^{31}$ Odnośnie do historii tych instytucji odesłać należy do: F. B ą c z k o w i c z C M, Prawo kanoniczne..., s. 466-468, n. 508, s. 540-541, n. 584; A. B r i d e, Calomnie [w:] Catholicisme: hier-aujourd'hui-demain, t. II, red. G. J a c q u e m e t, Paris 1949, kol. 396-397; P. D a u b e r c i e s, Réputation [w:] Catholicisme..., t. XII, red. G. M a t h o n, G. - H. B a u d r y, E. T h i e r y, Paris 1990, kol. 939-940; J. D e n i s, Infamie [w:] Catholicisme..., t. V, red. G. J a c q u e m e t, Paris 1962, kol. 1572-1573; J. G r z y w a c z, Infamia [w:] Encyklopedia katolicka, t. VII, red. S. W i e $1 \mathrm{~g} \mathrm{u}$ s, J. D u c h n i e w s k i, Lublin 1997, kol. 187; N . I u n g, Calomnie [w:] Dictionnaire de droit canonique, red. R. N a z, t. II, Paris 1937, kol. 1267-1269; B. L ö b m a n n, Der kanonische Infamiebegriff in seiner geschichtlichen Entwicklung. Unter besonderer Berücksichtigung der Infamielehre des Franz Suarez, Leipzig 1956; G. M a y, Infamie [w:] Lexikon für Theologie und Kirche, red. J. H ö f e r, K. R a h n e r, t. V, Freiburg 1960, kol. 667; A. M ü h 1 e $\mathrm{b}$ a c h, Die Infamie in der decretalen Gesetzgebung, Paderborn 1923; R. N a z, Diffamation [w:] Dictionnaire..., t. IV, Paris 1949, kol. 1224-1225; t e n ż e, Infamie [w:] tamże, t. V, Paris 1953, kol. 1358-1360; J. W e r c k m e i s t e r, Petit dictionnaire de droit canonique, Paris 1993, s. 119, hasło: Infamie (infamia).

${ }^{32}$ Zob. jednak A. P e r e g o, La buona fama..., s. 51-76.

${ }^{33} \mathrm{Na}$ te powołuje się też wydawca Codex Iuris Canonici auctoritate Ioannis Pauli PP. II promulgatus. Fontium annotatione et indice analytico-alphabetico auctus, red. Pontificia Commissio Codici Iuris Canonici Authent i c e I n t e r p r e t a n d o, Città del Vaticano 1989 - podając n. 26 i 27 Gaudium et spes $\mathrm{S}$ o b o r u Wa t y kań s k i e g o I I oraz encyklikę Pacem in terris $\mathrm{J}$ a $\mathrm{n}$ a X X I I I z 11 kwietnia 1963 (AAS 55 [1963] 260).

${ }^{34}$ Stąd może niezbyt udana redakcja negatywna przepisu części pierwszej kan. 220, aczkolwiek prezentowane jest w literaturze kanonistycznej także stanowisko, że właśnie na tym ma polegać ochrona praw fundamentalnych w Kościele - ma ona być przede wszystkim negatywna (la garanzia „negativa”), zakazywać czynów naruszających te prawa; por. C. M i r a b e 11 i, La protezione giuridica dei diritti fondamentali [w:] Les Droits Fondamentaux du Chrétien dans l'Eglise et dans la Société. Actes du IV Congrès International de Droit Canonique, red. E. C o r e c c o, N. H e r z o g, A. S c o 1 a, Fri- 
w art. 12 Powszechnej Deklaracji Praw Człowieka z 10 grudnia 1948 r. $^{35}$

Papieska Komisja dla Rewizji Kodeksu Prawa Kanonicznego (Pontificia Commissio Codici Iuris Canonici Recognoscendo), ustanowiona przez Jana XXIII dnia 28 marca 1963 r., wkrótce po zakończeniu I sesji Soboru Watykańskiego II, formalnie swoje prace kodyfikacyjne rozpoczęła od sesji plenarnej konsultorów, czyli dnia 6 maja 1965 r. Pierwsze obrady dotyczyły kwestii fundamentalnych. Sobór trwał do dnia 8 grudnia 1965 r. Jednak również i po nim biskupi całego świata mieli wpływ na kształt przyszłego prawodawstwa Kościoła łacińskiego. Centralny zespół konsultorów bowiem wypracował tzw. Principia quae Codicis Iuris Canonici recognitionem dirigant (Zasady, które winny kierować odnowa kodeksu prawa kanonicznego). Przedyskutowane w Komisji na sesji w dniach 3-8 kwietnia 1967 r. oraz wniesione na obrady pierwszej sesji Synodu Biskupów w dniach 30 września - 4 października 1967 r. - Principia wiązały kodyfikatorów. Kwestia jest o tyle istotna, że wśród tych zasad znalazł się postulat, aby prawa fundamentalne wszystkich

bourg Suisse 1981, s. 415. W każdym razie pod względem redakcyjnym część pierwsza kan. 220 jest ewenementem w grupie przepisów tytułu I. części I. księgi II. Wszystkie bowiem przepisy tej jednostki systematycznej CIC zostały zredagowane pozytywnie: wierni mają prawa i obowiązki pozytywnie określone. Por. podobnie F. C o m p a g n o n i OP, Prawa człowieka. Geneza, historia i zaangażowanie chrześcijańskie, przekł. S. B i e l a ń s k i, Kraków 2000, s. 244. Ponadto w przemówieniu do kanonistów, zebranych na międzynarodowym kongresie, dnia 25 maja 1968 papież Paweł VI przedłożył im Powszechną Deklarację Praw Człowieka z 1948 r. jako jedno ze źródeł, które należy uwzględnić przy rewizji CIC; cyt. za: P. L o m b a r d í a, Die Grundrechte des Gläubigen, Concilium 5 (1969) nr 10, s. 608-609, 611 z przyp. 7. W czasie prac Ojców Soboru Watykańskiego II również odwoływano się do Powszechnej Deklaracji Praw Człowieka z 1948 r.; por. A. P e r e g o, La buona fama..., s. 90-91, przyp. 31.

$\mathrm{Na}$ to, że jednym ze źródeł kan. 220 był art. 12 Powszechnej Deklaracji Praw Człowieka z 10 grudnia 1948 r., wskazuje też umieszczenie w jednym kanonie dwóch norm - chroniącej dobre imię i chroniącej sferę prywatności. Racją umieszczenia w tym samym przepisie dwóch różnych norm jest pewne podobieństwo tych dwóch dóbr osobistych i trudność w wyraźnym rozgraniczeniu zakresu ochrony obu tych dóbr. To wystarczający powód, aby ochrona dobrego imienia i prywatności regulowana była w jednej jednostce systematycznej CIC. Natomiast błędnym wydaje się - i tego błędu nie popełniają powoływane wyżej dokumenty prawa międzynarodowego - umieszczenie w jednej jednostce redakcyjnej tekstu prawnego ochrony tych dwóch dóbr osobistych, ale w odmiennej redakcji, tj. odnośnie do dobrego imienia bez kwalifikacji jego ochrony jako prawa, natomiast w przypadku prywatności już jako prawa do (ius ad).

${ }^{35}$ Nie wolno ingerować samowolnie w czyjekolwiek życie prywatne, rodzinne, domowe, ani w jego korespondencję, też uwtaczać jego honorowi lub dobremu imieniu. Każdy człowiek ma prawo do ochrony prawnej przeciwko takiej ingerencji lub uwłaczaniu. 
osób w Kościele były określone i zabezpieczone, włącznie z ochroną praw podmiotowych (n. 6 i 7 Principia) $)^{36}$.

Nic więc dziwnego, że ochronę dobrego imienia zaproponowały dwa zespoły kodyfikacyjne Papieskiej Komisji - redagujący schemat de Laicis oraz redagujący schemat Lex Ecclesiae Fundametalis. Odpowiednio też można mówić o dwóch fazach kształtowania się treści normatywnej kan. 220 część pierwsza.

$\mathrm{W}$ pierwszej fazie prac legislacyjnych, tj. w pracach zespołu de Laicis, powołanego w styczniu $1966 \mathrm{r}^{37}$, już w $1967 \mathrm{r}$. w projekcie kan. 2 \& 2 - w Relatio circa statutum iuridicum generale omnium christifidelium, zredagowanym przez relatora Alvaro Del Portil$\mathrm{lo}^{38}$ - znalazło się sformułowanie: Fidelium ius est, ut in congruo habeantur honore et bona existimatione afficiantur neque bona fama indebite priventur ${ }^{39}$. W trakcie zatem sesji II tego zespołu, w dniach 16-21 października 1967 r., przedmiotem obrad był ów projekt. Kardynał Felici pozytywnie wypowiedział się o projekcie; podkreślił pozytywny sposób sformułowania prawa, wyodrębnionego we własnej jednostce redakcyjnej tekstu prawnego, a także zwrócił uwagę na szczególną rolę ochrony dobrego imienia we współczesnym świecie ${ }^{40}$. Jak widać, na tym etapie kształtowania treści przepisu części pierwszej kan. 220 pojawiają się - chyba dosyć przypadkowo i bez głębszej refleksji - słowa: existimatio, honor i bona fama.

W. Onclin zaproponował nową redakcję tego kanonu, uzyskując aprobatę wszystkich ${ }^{41}$. Tekst schematu, który opracowany zo-

${ }^{36}$ Por. bp P. H e m p e r e k, W. G ó r a 1 s k i, Komentarz do Kodeksu Prawa Kanonicznego z 1983 r., t. 1/I: Historia źródet i nauki prawa kanonicznego, Lublin 1995, s. 134, 148-149; J. K r u k o w s k i, Prawa wiernych do dobrej opinii..., s. 227; A. P e r e g o, La buona fama..., s. 90-91, przyp. 31 z cyt. źródłami.

${ }^{37}$ Zob. A. C a u t e r u c c i o, Il diritto alla buona fama..., s. 40, przyp. 2.

${ }^{38}$ Por. tamize, s. 40-41.

${ }^{39}$ Pontificia Commissio Codici Iuris Canonici Rec o g n o s c e n d o, Coetus Studiorum „De Laicis” (Sessio II), Communicationes 17 (1985) nr 2, s. 210. Zob. też A. C a u t e r u c c i o, Il diritto alla buona fama..., s. 41. Por. J. K r u k o w s k i, Prawa wiernych do dobrej opinii..., s. 229-230, gdzie też następujący przekład polski: Wierni mają prawo do tego, aby posiadali należny im honor $i$ cieszyli się dobrym poważaniem, ani też nie pozbawiano ich niesprawiedliwie dobrej opinii.

${ }^{40}$ Por. Pontificia Commissio Codici I u r is Canonici Rec o g n o s c e n d o, Coetus Studiorum „De Laicis” (Sessio II)..., s. 211.

${ }^{41}$ Zob. Pontificia Commissio Codici Iuris Canonici Rec o g n o s c e n d o, tamże. Por. też A. C a u t e r u c c i o, Il diritto alla buona fama..., s. 42 . 
stał przez W. Onclina, sekretarza pomocniczego Papieskiej Komisji, z uwzględnieniem wniosków kard. P. Felici i konsultorów zespołu de Lege Ecclesiae fundamentali, brzmiał: Fidelium ius est ut bona fama gaudent ab omnibus in honorem habeantur; quapropter nemini licet illegitime eandem laedere ${ }^{42}$. W projekcie tym zatem bardziej podkreślono pozytywne wypowiedzenie prawa do dobrego imienia ${ }^{43}$. Jeżeli zaś chodzi o verba legis ferendae, to co prawda nie pojawia się już existimatio, ale nadal wybór ten zdaje się być dość przypadkowy.

Przepis ten otrzymał numer 17 w Statutum iuridicum omnium christifidelium. Następnie był dyskutowany przez zespół de Laicis na sesji V w dniach 28-31 stycznia 1970 r. oraz na sesji VI w dniach 7-11 kwietnia 1975 r. Po sesji V był niezmieniony; zmieniło się jedynie jego oznaczenie na kan. $18^{44}$. Komentując ów projekt kan. 18, W. Onclin m. in. stwierdził, że wymóg illegitime oznacza, że zgodne z prawem naruszenie dobrego imienia (na przykład zadeklarowanie zaciagnięcia kary latae sententiae) jest dopuszczalne ${ }^{45}$.

W rezultacie tak sformułowany kan. 18, po uzyskaniu pozytywnej oceny zespołu, został włączony do schematu De populo Dei jako kan. 32 i był konsultowany wśród biskupów świata w 1977 r. ${ }^{46}$ W dyskusji tej zauważono m. in., że to prawo do dobrego imienia jako fundamentalne nie opiera się tylko na chrzcie, jeżeli zaś ma być ów kanon zachowany, to tylko z uwzględnieniem momentu specyficznego dla Kościoła (uwagi episkopatów kanadyjskiego i australijskiego oraz Uniwersytetu w Ottawie). Wydział Prawa Ka-

${ }^{42} \mathrm{~W}$ przekładzie własnym: Wierni maja prawo do tego, aby cieszyli sie dobrym imieniem [bona fama] $i$ od wszystkich posiadali poszanowanie [honor]; dlatego nikomu nie wolno bezprawnie naruszać dobrego imienia [eandem]. Por. P o n t if i c i a C o m missio Codici I u ris Canonici Recognoscendo,tamże, gdzie też powołanie się na źródła prawa, tj. Pacem in Terris J a n a X X I I I; Unitatis Redintegratio, n. 12; Gaudium et Spes, n. 26. Por. też A. C a u t e r u c c i o, Il diritto alla buona fama..., s. 42.

${ }^{43}$ Zob. Pontificia Commissio Codici Iuris Canonici Rec o g n o s c e n d o,tamże; A. C a u t e r u c c i o, tamże.

${ }^{44}$ Por. Pontificia Commissio Codici Iuris Canonici Rec o g n o s c e n d o, Coetus Studii „De Laicis deque Associationibus Fidelium” (Sessio V), Communicationes 18 (1986) nr 2, s. 328; A. Cauteruccio, Il diritto alla buona fama..., s. 43 z przyp. 14, 16 .

${ }^{45}$ Por. A. Ca u t e r u c i o, Il diritto alla buona fama..., s. 43 z przyp. 18;

J. K r u k o w s k i, Prawa wiernych do dobrej opinii..., s. 230.

${ }^{46}$ Zob. A. C a u t e r u c c i o, Il diritto alla buona fama..., s. 44. 
nonicznego z Paryża w ogóle odrzucił celowość tej regulacji jako nie związanej ze chrztem. Podobnie bp Benitez z Barquisimento, stwierdzając, że prawo to już jest w prawie naturalnym. Nadto episkopat filipiński i Uniwersytet św. Tomasza na Filipinach, zauważając, że prawo do dobrego imienia występuje już w prawie moralnym. Natomiast episkopat holenderski zaproponował umieszczenie środków ochrony prawnej prawa do dobrego imienia ${ }^{47}$.

Jednakże dalsza dyskusja nad kan. 32 schematu De populo Dei nie była kontynuowana. Sekretarz Papieskiej Komisji, Castillo Lara, zdecydował bowiem o zniesieniu tegoż przepisu, gdyż był on identyczny z kan. 20 Lex Ecclesiae Fundamentalis ${ }^{48}$.

Druga faza powstawania treści obecnego kan. 220 części pierwszej przypada na prace w ramach zespołu redagującego Lex Ecclesiae Fundamentalis ${ }^{49}$.

W ramach prac tego zespołu po raz pierwszy prawo do dobrego imienia pojawiło się już podczas sesji II, tj. w dniach 3-7 marca 1967 r. (coetus centralis) ${ }^{50}$. Stosowny kan. 23 brzmiał: Christifidelibus ius est ut bona fama qua gaudent ab omnibus in honore habeatur; quapropter nemini licet illegitime eandem laedere ${ }^{51}$. Znalazł się on w pierwszym schemacie Legis Ecclesiae Fundamentalis z 1969 r. (textus prior) w ramach rozdziału I: De Ecclesia seu de Populo Dei ${ }^{52}$.

${ }^{47}$ Por. tamże, s. 44-45, gdzie cyt. P o n t if i c i a C o m m is s i o C o d i c i I u$\mathrm{r}$ is C a n o n i c i R e c o g n o s c e n d o, Schema Canonum Libri II De Populo Dei (reservatum), Typis Polyglottis Vaticanis 1977, t. I, s. 24.

${ }^{48} \mathrm{Pontificia}$ Commissio Codici Iuris Canonici Recog n o s c e n d o, Coetus Studiorum „De Populo Dei”, Communicationes 12 (1980) nr 1, s. 86. Zob. A. C a u t e r u c c i o, Il diritto alla buona fama..., s. 45.

${ }^{49} \mathrm{O}$ wcześniejszych pracach nad Lex Ecclesiae Fundamentalis zob. R. S o b a ń s k i, Refleksje o kościelnym prawie fundamentalnym, Śląskie Studia Historyczno-Teologiczne 5 (1972), s. 43-57, a zwłaszcza s. 43-44, gdzie podkreślono rolę praw fundamentalnych w przyszłym prawie fundamentalnym Kościoła.

${ }^{50}$ Zob. A. C a u t e r u c c i o, Il diritto alla buona fama..., s. 45-46 z przyp. 25.

${ }^{51} \mathrm{Pontificia} \mathrm{Commissio}$ Codici Iuris Canonici Recog n o s c e n d o, Acta et Documenta Coetus Specialis Studii de Lege Ecclesiae Fundamentali, t. II, pro manuscripto, s. 176 - cyt. za: A. C a u t e r u c c i o, Il diritto alla buona fama..., s. 46. W przekładzie własnym: Wierni maja prawo, aby dobre imię, którym się ciesza, byto przez wszystkich szanowane; dlatego nikomu nie wolno go bezprawnie naruszać. W przekładzie E. S z t a f r o w s k i e g o: Wiernym przystuguje prawo, by dobra opinia, jaka się ciesza, była uszanowana przez wszystkich: nie wolno jej przeto nikomu bezprawnie naruszać; zob. Posoborowe prawodawstwo kościelne, przekł. E. S z t a f r o w s k i, t. 3, z. 3, s. 115-116, nb. 6269.

${ }^{52}$ Por. A. C a u t e r u c c i o, Il diritto alla buona fama..., s. 47, gdzie powołanie 
Jak łatwo zauważyć, również w tej fazie dobór verba legis ferendae był raczej dość przypadkowy (bona fama, honor).

Następnie w 1970 r. kanon był konsultowany wśród kardynałów-członków Komisji oraz Św. Kongregacji Nauki Wiary, a także członków Międzynarodowej Komisji Teologicznej53. W wyniku tej konsultacji wskazano na słabsze strony redakcji omawianego kanonu. Krytykowano (kard. Caggiano, członek Komisji), że nie jest jasna racja, dla której nie uwzględniono innych praw naturalnych (np. prawa do życia, własności). Wskazywano na niewyraźne znaczenie słowa illegitime (Medina, konsultor Komisji); z drugiej zaś strony możliwość naruszenia dobrego imienia legitime (Betti ze Św. Kongregacji Nauki Wiary). Wydawało się konieczne także (kard. Doi, członek Komisji), aby w samym kanonie podkreślić konieczność naprawienia szkody wyrządzonej bezprawnym naruszeniem dobrego imienia. Na wszystkie te zarzuty odpowiedział całkowicie satysfakcjonująco W. Onclin, co spotkało się z aprobatą na IV sesji w dniach 19-23 maja $1970 \mathrm{r} .^{54}$

Stąd w tym samym kształcie i z tą samą numeracją kanon znalazł się w nowym wydaniu schematu Legis Ecclesiae Fundamentalis z 1971 r. (textus emendatus). Przeszedł drugą konsultację (wśród biskupów świata, Unii Wyższych Przełożonych, dykasterii Kurii Rzymskiej oraz konsultorów) i pojawił się jako kan. $26 \mathrm{w}$ schemacie zredagowanym przez W. Onclina w kwietniu 1973 r. W kolejnej redakcji W. Onclina z października 1973 r. kanon ów nosi już numer 20, będąc

się na: Pontificia Commissio Codici I u r is Canonici Rec o g n o s c e n d o: Schema Legis Ecclesiae Fundamentalis cum relatione (sub secreto), Typis Polyglottis Vaticanis 1969, s. 16. Tekst polsko-łaciński w: Posoborowe prawodawstwo kościelne..., t. 3, z. 3, s. 98-170.

${ }^{53}$ Por. A. C a u t e r u c c i o, Il diritto alla buona fama..., s. 47. Zarys prac zespołu redagującego Lex Ecclesiae Fundamentalis u: b p P. H e m p e r e k, W. G ó r a 1 s k i, Komentarz do Kodeksu Prawa Kanonicznego z 1983 r., t. 1/I: Historia..., s. 167-168.

${ }^{54}$ Zob. A. C a u t e r u c c i o, Il diritto alla buona fama..., s. 47-49 z cyt. P o n t i f i cia Commissio Codici I uris Canonici Recognoscendo, Acta et Documenta Coetus Specialis Studii de Lege Ecclesiae Fundamentali, t. III, pro manuscripto, s. 503. Por. A. C a u t e r u c c i o, tamże - cytowane zarzuty i odpowiedzi W. Onclina. Odnośnie do zarzutu kard. Caggiano: nie potrzeba wyraźnie stanowić w prawie kanonicznym prawa naturalnego do życia; prawo własności zaś potrzebuje stanowienia granic, tym zaś zajmuje się prawo cywilne, a nie kanoniczne. Odnośnie do zarzutu Mediny: nie ma trudności, gdyż czasami z powodu dobra wspólnego możliwe jest naruszenie dobrego imienia w sposób prawny. Odnośnie do zarzutu kard. Doi: nie ma potrzeby statuowania in casu zasady naprawienia szkody; to kwestia moralna. 
znacznie uproszczony: Nemini licet bonam famam qua quis gaudet illegitime laedere ${ }^{55}$. Nie są znane z protokołów prac zespołu motywy tak znacznego uproszczenia treści kan. 2056. Wynikiem tak znacznego skrócenia treści przepisu było zrezygnowanie ze słowa honor; obecnie na oznaczenie dobrego imienia zostały słowa bona fama.

Na sesji VII (17-22 grudnia 1973 r.) wokół kan. 20 toczyła się ożywiona dyskusja. Žužek poddał w wątpliwość, czy kan. 20 powinien znaleźć się w Lex Ecclesiae Fundamentalis. Majdzie nie wydawało się konieczne słowo illegitime, jednak Onclin przekonał wszystkich, że może nastąpić przecież legalne naruszenie dobrego imienia ${ }^{57}$.

W czerwcu 1977 r., już po raz trzeci, tekst schematu Legis Ecclesiae Fundamentalis został poddany konsultacjom, ale tym razem ograniczając się do członków-kardynałów Papieskiej Komisji dla Rewizji Kodeksu Prawa Kanonicznego oraz Papieskiej Komisji Odnowy Wschodniego Kodeksu Prawa Kanonicznego. Zdaniem kard. Palazzini należałoby opuścić słowo illegitime. Według kard. Florit nie jest dobre (opportunum) zamieszczanie tego przepisu, skoro jest to nakaz moralny, powszechny i naturalny. Podobnie wypowiedział się patriarcha Khoraiche: przecież są inne prawa indywidualne nie wymieniane w ustawie ${ }^{58}$.

W wypowiedziach kardynałów nie było wiec nic nowego. Treścią kan. 20 zajęła się sesja XI w dniach 24-29 września 1979 r., ograniczając się do stwierdzenia, że kan. 20 pozostanie i że jest użyteczny ${ }^{59}$.

Jako że w 1981 r. zarzucono ideę Lex Ecclesiae Fundamentalis, treść tego kan. 20 wraz z innymi 36 projektowanymi kanonami schematu została włączona do najnowszego schematu CIC z 1982 r. (Schema novissimum). Przepis ten został włączony do CIC jako część pierwsza kan. 220 i tak promulgowany w 1983 r. ${ }^{60}$ Ojciec Święty Jan Paweł II, obrońca praw człowieka, osobiście zdecydował

\footnotetext{
${ }^{55}$ We własnym przekładzie: Nikomu nie wolno bezprawnie naruszać dobrego imienia, którym ktoś się cieszy.

${ }^{56}$ Por. A. C a u t e r u c c i o, Il diritto alla buona fama..., s. 49.

${ }^{57}$ Zob. tamże, s. 49-50.

${ }^{58}$ Por. Pontificia Commissio Codici Iuris Canonici Rec o g n o s c e n d o, Coetus Specialis „De Lege Ecclesiae Fundamentali”, Communicationes 12 (1980) nr 1, s. 41. Por. nadto A. C a u t e r u c c i o, Il diritto alla buona fama..., s. 50-51.

${ }^{59}$ Zob. A. C a u t e r u c c i o, Il diritto alla buona fama..., s. 51.

${ }^{60}$ Por. tamże; J. K r u k o w s k i, Prawa wiernych do dobrej opinii..., s. 230.
} 
o rozciągnięciu ochrony prawnej w CIC także na sferę prywatności, która znalazła wyraz w drugiej części kan. $220^{61}$.

Wyciągając wnioski z tej historii redakcji przepisu części pierwszej kan. 220, należy przede wszystkim zauważyć, że dobrze się stało, iż ustawodawca kościelny uniknął zdefiniowania dobrego imienia . Również ustawodawstwa cywilne świeckie nie ulegają tej pokusie. Nie jest to potrzebne, a wręcz okazałoby się szkodliwe. Równie dobrze można więc powiedzieć o dobrym imieniu, czci czy też dobrej sławie człowieka; sa to pojęcia prawie że jednoznaczne ${ }^{62}$.

Język łaciński wszakże jest znacznie bogatszy znaczeniowo niż język polski. Dlatego należy poddać krytyce zbędne zamieszanie terminologiczne. Wydaje się bowiem, że ustawodawca nie zdawał sobie do końca sprawy z tego, co kryje się za poszczególnymi pojęciami: fama, existimatio, infamia - i jaką one mają za sobą przeszłość. Stąd można dojść do uprawnionego wniosku, że verba legis nie miały większego znaczenia dla ustawodawcy, kiedy chronił dobre imię w Kodeksie z 1983 r. Można też przypuszczać, że tego typu postawa ustawodawcy jedynie utrudni proces interpretacji tego, co przez słowa bona fama ustawodawca w części pierwszej kan. 220 rozumiał.

\section{Zakres przedmiotowy pojęcia dobrego imienia w części pierwszej kan. 220}

\subsection{Ochrona czci w ustawodawstwach świeckich na przykładzie prawa polskiego}

Ustawodawca polski w powoływanym już art. 23 k.c. stanowi, że cześć pozostaje pod ochroną prawa cywilnego niezależnie od ochrony przewidzianej w innych przepisach. Charakterystyczne, że ustawodawca polski posłużył się słowem cześć, choć miał do wyboru inne jeszcze określenia, jak na przykład: dobre imię, dobra sława, dobra opinia, reputacja, honor, godność osobista. W każdym razie zagadnienie jest kluczowe ze względu na doniosłość społeczną,

${ }^{61}$ Zob. J. K r u k o w s k i, Prawa wiernych do dobrej opinii..., s. 234.

${ }^{62}$ Zob. pod rządem przepisu art. 23 k.c. wyrok SN z dnia 29 października 1971 r., sygn. II CR 455/71, OSNCP 1972, nr 4, poz. 77, którego tezę przytacza M. R o z w a d o w s k a - H e r r m a n n, tamże, s. 24, t. 3. 
a terminy używane są czasem zamiennie, jakkolwiek już intuicyjnie się wyczuwa, że nie są to synonimy ${ }^{63}$.

W cywilistyce przyjmuje się powszechnie, że cześć jest pojęciem nadrzędnym. Przejawia się zaś w dwóch aspektach - zewnętrznym (dobre imię) i wewnętrznym (godność osobista). O ile aspekt zewnętrzny odnosi się do opinii, jaką o wartości danego człowieka mają inni ludzie, o tyle aspekt wewnętrzny czci dotyczy godności osobistej człowieka, jego wyobrażenia o własnej wartości. Do rozróżnienia tego nawiązuje też kodeks karny i nauka prawa karnego ${ }^{64}$.

W polskim zatem prawie cywilnym i karnym cześć rozumiana jest jako godność i jako dobre imię. Pojęcia te nie są więc tożsame. Godność oznacza szczególną wartość człowieka jako osoby, pozostającej w relacjach interpersonalnych, uzasadniających i usensowniających życie osobowe, a także pozytywnie wartościującą relację do własnej osoby i grupy. Chodzi więc o samoocenę, polegająca na przeżywaniu własnej wartości i pozytywnego obrazu siebie. Zakłada to poczucie wewnętrznej wolności, autodeterminacji i odpowiedzialności ${ }^{65}$.

Podobnie wypowiadają się polskie sądy. Sąd Najwyższy w wyroku z dnia 8 października 1987 r. ${ }^{66}$ wypowiedział pogląd, że godność osobista jest tą sferą osobowości, która konkretyzuje się w poczuciu własnej wartości człowieka i oczekiwaniu szacunku ze strony innych ludzi. Poczucie to, istotny element psychiki człowieka, kształtowane jest przez szereg zewnętrznych czynników. Stąd zmienność tego poczucia, jego historyczno-kulturowe uwarunkowanie, zależność od osobowości człowieka. Natomiast Sąd Apelacyjny w Krakowie w wyroku z dnia 21 marca 1995 r. ${ }^{67}$ stwierdził, że godność osobista

${ }^{63}$ Por. A. S z p u n a r, Ochrona..., s. 127.

${ }^{64} \mathrm{~W}$ art. 212 kodeksu karnego z 1997 r. opisano typ czynu zabronionego, jakim jest pomówienie. Natomiast w art. 216 kodeksu karnego mowa jest o znieważeniu jako innym typie czynu zabronionego. Oba te typy czynów zabronionych ustawodawca karny polski umieścił w jednym rozdziale, nazywając je przestęstwami przeciwko czci. Por. również A. S z p u n a r, Ochrona..., s. 127-128. Podobnie też judykatura polska; zob. uchwałę 7 sędziów SN z dnia 28 maja 1971 r. (OSNCP 1971, poz. 188).

${ }^{65}$ Zob. J. C h a c i ń s k i, Prawa podmiotowe a ochrona dóbr osobistych, Lublin 2004, s. $123-124$.

${ }^{66}$ Zob. wyrok SN z dnia 8.10.1987 r., sygn. II CR 269/87, OSNCP 1989, nr 4, poz. 66.

${ }^{67}$ Por. wyrok Sądu Apelacyjnego w Krakowie z dnia 21.03.1995 r., sygn. I ACr 113/95, Dobra osobiste. Zbiór orzeczeń Sądu Apelacyjnego w Krakowie, opr. B. G a w 1 i k, Kraków 1999, s. 155-161. 
przysługuje każdej osobie i podlega ochronie prawnej niezależnie od tego, w jaki sposób kształtuje się obraz danej osoby w opinii innych. O przyznaniu takiej ochrony rozstrzyga $\mathrm{z}$ normatywnego punktu widzenia uznanie podmiotowości każdego człowieka, z aksjologicznego zaś punktu widzenia fundamentalny postulat szanowania w każdym człowieku jego osoby ludzkiej.

Jasne rozróżnienie czci i dobrego imienia w polskim prawie cywilnym i karnym nie jest jednak tak oczywiste w prawie pracy. $\mathrm{W}$ art. $11^{1}$ kodeksu pracy wyróżniona została godność pracowni$\mathrm{cza}^{68}, \mathrm{z}$ drugiej zaś strony w art. 300 ustawodawca odesłał do przepisów kodeksu cywilnego w sprawach nie unormowanych kodeksem pracy.

Podobny problem powstaje przy przepisach Konstytucji RP, która w art. 47 stanowi o ochronie prawnej czci i dobrego imienia. Zdaje się wiec sugerować, że cześć nie jest pojęciem nadrzędnym wobec pojęcia dobrego imienia. Wydaje się jednak, że charakter przepisu (konstytucyjny) i zestawienie szeregu dóbr w tym przepisie (życie prywatne, rodzinne, cześć, dobre imię i decydowanie o swoim życiu osobistym) przesądza o tym, że polski ustawodawca konstytucyjny przedmiot ochrony prawnej zakreśla bardzo szeroko - tak w aspekcie wewnętrznym, jak i zewnętrznym czci, o którym mowa w prawie cywilnym i karnym ${ }^{69}$.

\subsection{Zakres przedmiotowy ochrony dobrego imienia (bona fama) z kan. 220}

W kan. 220 ustawodawca kościelny chroni dobre imię (bona fama), a jednocześnie prawo każdej osoby do własnej intymności, prywatności (propria intimitas). Problemem staje się wszakże interpretacja słów bona fama. Możliwe jest bowiem zajęcie stanowiska, że bona fama oznacza jedynie dobre imię, czyli termin ten obejmowałby tylko aspekt zewnętrzny czci. Jednakże można by bronić odmiennego zapatrywania, tj. że bona fama obejmuje tak zakres zewnętrzny (dobre imię), jak i zakres wewnętrzny czci (godność osobistą).

${ }^{68}$ Przepis art. $11^{1}$ kodeksu pracy brzmi: Pracodawca jest obowiazany szanować godność $i$ inne dobra osobiste pracownika.

${ }^{69}$ Byłoby to powtórzenie poglądu polskiego Sądu Najwyższego z wyroku z dnia 29.10.1971 r., sygn. II CR 445/71, OSNCP 1972, nr 4, poz. 77: cześć, dobre imię, dobra sława człowieka są pojęciami obejmującymi wszystkie dziedziny jego życia osobistego, zawodowego i społecznego. 
Za pierwszym poglądem, tj. że zakres przedmiotowy bona fama z kan. 220 obejmuje tylko zakres zewnętrzny czci, czyli dobre imię, reputację, dobrą opinię - przemawia wykładnia językowa kan. 220. Sugerują ten sposób podejścia również polskie tłumaczenia: dobre imie $^{70}$, dobra opinia ${ }^{71}$, dobra stawa ${ }^{72}$. Co więcej, w przepisach kan. 1390 § 2 i 3 mowa jest o laesio bonae famae (naruszenie dobrego imienia) i calumniosa denuntiatio (oszczercze doniesienie). Natomiast w kan. 2355 CIC z 1917 r. ustawodawca kościelny stanowił nie tylko o laesio bonae famae, dotyczącej aspektu zewnętrznego czci (zniesławienie), ale także wyraźnie o iniuria (zniewaga), dotyczącego aspektu wewnętrznego czci $^{73}$. Zaszła więc wyraźna zmiana stanu prawnego w tym zakresie ${ }^{74}$. O tym, że na podstawie przepisów Kodeksu Jana Pawła II bona fama oznacza jedynie cześć w znaczeniu zewnętrznym, a nie wewnętrznym - przekonują zatem także przepisy o charakterze karnistycznym, interpretowane przecież zawężająco (kan. 18).

${ }^{70}$ Por. Kodeks Prawa Kanonicznego. Przekład polski..., kan. 220; W. G ó r a 1 s k i, Lud Boży. Kościelne prawo osobowe, Częstochowa 1996, s. 24; E. S z t a f r o w s k i, Podręcznik prawa kanonicznego, t. I, Warszawa 1985, s. 299.

${ }^{71}$ Zob. J. K r u k o w s k i, Katalog..., s. 50-51. Zresztą podobnie w literaturze włoskiej, gdzie mowa jest o pozytywnej opinii (il giudizio positivo), którą ktoś się cieszy wśród tych, którzy go znają, i mają o nim dobre zdanie, jeżeli chodzi o uczciwość, moralność i religijność; por. V. T i z i a n o, [w:] Codice di Diritto Canonico commentato, red. Redakcja „Quaderni di diritto ecclesiale”, Milano 2001, s. 234.

${ }^{72}$ Zob. T. P a w 1 u k, Prawo kanoniczne..., t. II, s. 42 - obok propozycji thumaczenia: dobre imię.

${ }^{73}$ Por. T. P a w 1 u k, Kanoniczne przestępstwo zniewagi i zniesławienia, Studia Warmińskie 18 (1981), s. 446. Byłoby więc to rozróżnienie czci w aspekcie wewnętrznym i zewnętrznym podobne do tego, jakie znane jest ustawodawstwom świeckim.

${ }^{74}$ Tak np. J. S y r y j c z y k, Kanoniczne prawo karne..., s. 144, który reprezentuje stanowisko - w świetle kan. 18 jak najbardziej, moim zdaniem, słuszne - że przedmiotem typu czynu zabronionego zniesławienia z kan. 1390 § 2 jest ,cześć zewnętrzna człowieka”. Zatem nie obejmują znamiona typu czynu, opisanego w kan. 1390 § 2, zniewagi. Ewentualnie ochrona czci w aspekcie wewnętrznym dokonywałaby się - moim zdaniem - na podstawie kan. 1399 (norma ogólna). Rozszerzająca wykładnia terminu bona fama jest bowiem, jak była mowa, wykluczona.

Inaczej w tej kwestii F. L e m p a [w:] bp W. W ó j c i k, J. K r u k o w s k i, F. L e m p a, Komentarz do Kodeksu Prawa Kanonicznego z 1983 r., t. 4: Ksiega V. Dobra doczesne Kościoła. Księga VI. Sankcje w Kościele, Lublin 1987, s. 268, twierdząc, że: „z ogólnego sformułowania można wywnioskować, że z całą pewnością obejmują one [działania naruszające cudze dobre imię - P.S.] podane w kan. 2355 KPK z 1917 r. przestępstwa zniewagi i zniesławienia”. 
Wydaje się jednak, że pogląd powyższy, ograniczający pojęcie bona fama jedynie do aspektu zewnętrznego czci człowieka, czyli do dobrego imienia właśnie - byłby znacznym zawężeniem woli ustawodawcy kościelnego w kan. $220^{75}$.

Po pierwsze, za rozszerzeniem rozumienia bona fama na aspekt również wewnętrzny, czyli godności człowieka, przemawia wykładnia systemowa. W tym samym bowiem tytule, w przepisie kan. $212 \S 3$, ustawodawca kościelny wspomina o szacunku wobec pasterzy (reverentia erga Pastores) i godności osoby (personarum dignitas). Co więcej, w kan. 208 mowa jest o równości co do godności (quoad dignitatem) wszystkich wiernych.

Argument ten jednak jest o tyle słaby, że można stwierdzić, że skoro ustawodawca kościelny nie wspomniał o ochronie godności ludzkiej w kan. 220, a w innych przepisach owszem, to znaczy, że nie chciał, aby zakres przedmiotowy ochrony na podstawie kan. 220 obejmował cześć w aspekcie wewnętrznym. Nawet jeżeli uznać, że zakres przedmiotowy ochrony na podstawie kan. 220 obejmuje tak aspekt zewnętrzny, jak i wewnętrzny czci człowieka (ten drugi zaś byłby chroniony na podstawie częśsi drugiej, dotyczącej ochrony intymności) - to i tak nie można by interpretować bona fama rozszerzająco w rozumieniu także godności człowieka. Godność człowieka byłaby bowiem chroniona przez część drugą kan. 220 poprzez ochronę intymności.

Ten sposób argumentacji można by podważyć, wskazując, że nie jest możliwe wyraźne zakreślenie obszaru intymności osoby i precyzyjne oddzielenie tego, co prywatne i osobiste, sekretne, domagające się zachowania tajemnicy - od tego, co podpada pod określenie bona fama, czyli ochrony dobrego imienia. Niejednokrotnie obszary obu tych sfer prawnie chronionych będą się pokrywały, np. kiedy chodzi o dobrą opinię, będącą warunkiem piastowania w Kościele wielu urzędów czy też przyjęcia święceñ $^{76}$. Wydaje się zatem, że to jest powód, dla którego ustawodawca kościelny umieścił ochronę dobrego imienia i intymności w jednym przepisie.

${ }^{75}$ Przepisy o charakterze prawnokarnym należy bowiem traktować w sposób szczególny, a to ze względu na normę interpretacyjną zawartą w kan. 18.

${ }^{76}$ Zob. P. M a j e r, Ochrona prywatności w kanonicznym porządku prawnym [w:] Ochrona danych osobowych i prawo do prywatności w Kościele, red. P. M a j e r, Kraków 2002, s. 95-97. 
Po drugie, pojęcia: cześć, dobra stawa, dobre imię, dobra opinia itd. - nie są pojęciami ostrymi. Również ustawodawstwo świeckie wskazuje na pewną nieostrość tych pojęć, stąd też i niedookreśloność zakresu przedmiotowego. Tak ustawodawcy świeccy, jak i ustawodawca kościelny słusznie unikają definicji czci czy dobrego imienia. Pozostawiają więc kwestię zakresu przedmiotowego ochrony z kan. 220 wykładni. Ta zaś - przy zastosowaniu metody prawnoporównawczej - sugeruje rozszerzającą wykładnię pojęcia bona fama z kan. 220. Trzeba bowiem wziąc pod uwage niejako konstytucyjny charakter przepisów zawartych w tytule I, części 1, księgi II. Oznacza to specyfikę sformułowania praw oraz ich interpretacji, jak na przykład w Konstytucji RP.

Po trzecie, jeżeli przyjąć, że pewien wpływ na sformułowanie kan. 220 miało międzynarodowe prawo publiczne, dotyczące praw człowieka, to zawsze ochrona prawna dobrego imienia łączy się z ochroną czci, godności ludzkiej, honoru ${ }^{77}$. Stąd wykładnia historyczna zmierza do rozszerzającej interpretacji kan. 220 .

Po czwarte, nawet gdyby przyjąć, że w kan. 220 nie jest wprost wyrażona ochrona czci w jej aspekcie wewnętrznym, to przyjęcia tej ochrony domaga się nauczanie Kościoła. Sobór Watykański II w Gaudium et spes wyraźnie wspomina jednocześnie o prawie do dobrego imienia i szacunku (ius ad bonam famam, ad reverentiam $)^{78}$. Również Jan XXIII w encyklice Pacem in terris domagał się prawa do należnego człowiekowi szacunku, do posiadania dobrej opinii ${ }^{79}$.

Po piąte, nie lada znaczenie ma też argument teoretycznoprawny, a ściślej z zakresu teologii prawa kanonicznego. Jeżeli bowiem porządek moralny w Kościele ma walor prawny, a prawo służy zbawieniu dusz (por. kan. 1752) ${ }^{80}$, to nie ulega wątpliwości, że pod ochroną prawa kanonicznego pozostaje też cześć w jej aspekcie

${ }^{77}$ Por. art. 12 Powszechnej Deklaracji Praw Człowieka z dnia 10 grudnia 1948 r. oraz uwagi wyżej 2.3., odnośnie do historii powstania przepisu kan. 220.

${ }^{78}$ Por. n. 26, 2.

${ }^{79}$ Zob. n. 12.

${ }^{80}$ Zob. choćby R. S o b a ń s k i, Zarys teologii prawa kościelnego, Warszawa 1973, s. 123-126; G. E r 1 e b a c h, Illicitas - pojecie prawne czy tylko moralne? Referat wygłoszony na konferencji naukowej 9 maja 2005 r. w Lublinie pt. Forum externum i forum internum $w$ prawie kanonicznym. Miedzy sumieniem a prawem, maszynopis - powoływane za: A. B r z e m i a - B o n a r e k, Dopuszczalność dowodów..., s. 52-53, 75. 
wewnętrznym. Pozostaje jednak nadal otwarta kwestia, czy podstawą prawną tej ochrony jest część pierwsza czy też druga kan. 220, czy też może inny przepis KPK, np. kan. 208.

Nie można też zupełnie odrzucić wykładni systemowej kan. 220, jeżeli przepis ten ma charakter normy ogólnej dla szeregu przepisów szczegółowych w KPK, które chronią dobre imię człowieka. To jednak wymaga szczegółowej analizy zakresu przedmiotowego norm zawartych w tych przepisach.

\subsection{Zakres przedmiotowy ochrony dobrego imienia w innych przepisach KPK}

Terminy: bona fama, fama, bona exsistimatio, fama integra, o których mowa w przepisach kan. $378 \S 1$ n. 2, $483 \S 2,1029,1048,1352 \S$ $2,1361 \S 3,1390 \S 2,1420 \S 4,1421 \S 3,1435,1455 \S 3,1483,1548 \S 2$ n. 2, $1717 \S 2$ oraz kan. 1741 n. 3 - zakładają ochronę czci w zakresie zewnętrznym (dobre imię). Tak więc kan. 378 § 1 n. 2 stanowi warunek dobrej opinii (bona exsistimatio) dla kandydatów na biskupów. $\mathrm{Z}$ kolei inne przepisy stanowią, że kanclerz i notariusze w kurii diecezjalnej (kan. $483 \S 2$ ), wikariusz sądowy i pomocniczy wikariusze sądowi (kan. 1420 § 4), sędziowie (kan. 1421 § 3), rzecznik sprawiedliwości i obrońca węzła (kan. 1435) mają być nieposzlakowanej opinii (integra fama), natomiast pełnomocnik i adwokat (kan. 1483) - nienaruszonej sławy (bonae famae). Do święceń zgodnie z kan. 1029 należy dopuszczać jedynie tych, którzy mają dobrą opinię (bona existimatio). Utrata zaś dobrego imienia (bonae existimationis amissio) może spowodować usunięcie proboszcza z parafii (kan. 1741 n. 3).

Kościół czuwa nad ochroną dobrego imienia (famam tuere w kan. $1361 \S 3$ ), chroniąc przed zniesławieniem (infamia) w kan. 1048, $1352 \S 2$ i 1548 \& 2 n. 2. Prawo karne kanoniczne zna typ czynu zabronionego w postaci oszczerczego doniesienia o przestępstwie (calumniosa delicti denuntiatio) i zniesławienia (laesio bonae famae) - kan. $1390 § 2$. Gdyby rozpowszechnienie akt lub dowodów w sprawie w procesie przed sądem kościelnym prowadziło do zagrożenia dobrego imienia innych (aliorum fama), sędzia może zobowiązać do zachowania tajemnicy pod przysięgą świadków, biegłych, strony, ich adwokatów lub pełnomocników (kan. 1455 §). W procesie karnym, już na etapie dochodzenia wstępnego (investigatio), w kan. 1717 § 2 stanowiona jest zasada, zgodnie z którą na- 
leży się zadbać o to, by wskutek takiego dochodzenia nie ucierpiało czyjeś dobre imię (bonum cuiusquam nomen).

Jak z powyższego widać, wszystkie te określenia dobrego imienia zawężone są do ścisłego rozumienia tego terminu: chodzi o dobrą sławę, dobą opinię, a nie o godność ludzką czy cześć. Oczywiście, pozostaje pewien margines niedookreślenia tych terminów, wynikający z ich nieostrości, który wkracza w dziedzinę wewnętrzną czci człowieka, jego godności. Zasadniczo jednak w przepisach szczegółowych Kodeks Jana Pawła II rozumie przez dobre imię aspekt zewnętrzny czci człowieka.

Jednak ochrona dobrego imienia w KPK nie ogranicza się jedynie do przepisów, w których wprost jest o tym mowa. Niewątpliwie przecież ochrona dobrego imienia, ale i czci, godności ludzkiej, wręcz intymności - wpisana jest w instytucję tajemnicy spowiedzi (kan. 982-985, 1388 i $1550 \S 2$ n. 2$)^{81}$. Poza tym przepisy o archiwach kościelnych zawarte w KPK chronią dobre imię (np. kan. 487 i $535 \S 4$ część druga czy też kan. $555 \S 1 \mathrm{n} .3$ oraz $§ 3$ część druga ${ }^{82}$. Ochronie dobrego imienia służą też chociażby przepisy o wykonywaniu władzy rządzenia w zakresie wewnętrznym (por. kan. 130), o tajemnicy ojców duchownych w seminariach (kan. 240 § 2), o tajemnicy pracowników kurii diecezjalnej (kan. 471 n. 2), o dyspensie od przeszkód tajnych (kan. 1048, kan. 1079 § 3 i kan. 1082). Ochronie dobrego imienia może też służyć kan. 1598 § 1, umożliwiający sędziemu niepublikowanie jakiegoś aktu procesowego. Ponadto przepis kan. $1548 \S 2$ n. 2 stanowi, że odmówić udzielenia odpowiedzi w procesie mogą świadkowie, którzy dla siebie lub krewnych czy powinowatych obawiają się zniesławienia (infamia)

${ }^{81}$ Por. J. S y r y j c z y k, Ochrona tajemnicy spowiedzi $w$ świetle kanonicznego prawa karnego, PK 44 (2001) nr 1-2, s. 119, 123.

${ }^{82}$ To bardzo praktyczne zagadnienie jest niemal nieobecne w literaturze. Z polskiej literatury zob. A. W e i s s, Archiwa kościelne w „Codex Iuris Canonici” papieża Jana Pawła II, RTK 31 (1984) nr 4, s. 115-124; H. M i s z t a 1, Sytuacja prawna archiwum parafialnego, Roczniki Nauk Prawnych 12 (2002) nr 2, s. 87-102. Por. też: A. M a 1 o n e OFM, Privacy - Reputation - Archives. A Canonical Overview, Newsletter of the Canon Law Society of Australia and New Zealand 1994, Spring, s. 16-17; R. O m b r e s OP, Privacy, Reputation and Archives, Canon Law Society of Great Britain and Ireland Newsletter 103 (1995), s. 52.

Bardzo dziękuję br. B e n e d y k t ow i Ł. J o n a k ow i OP z Prowincji Angielskiej za pomoc w uzyskaniu materiałów od Autorów, a także T h e C a n o n L a w Society of Great Britain and Ireland - za ich udostępnienie. 
czy niebezpiecznych przykrości (periculosae vexationes). O ile zniesławienie oznacza ochronę czci w aspekcie zewnętrznym, o tyle pod pojęciem niebezpieczne przykrości należy widzieć przede wszystkim cześć w aspekcie wewnętrznym ${ }^{83}$.

W każdym razie zakres ochrony dobrego imienia i czci człowieka, stanowiony w tych przepisach szczegółowych, pokrywa się z zakresem przedmiotowym ochrony przyznawanej w kan. 220. Przepis kan. 220 byłby więc normą ogólną, mającą charakter zasady prawnej, spinajacą niejako system prawa kanonicznego w zakresie ochrony dobrego imienia i czci człowieka. Takie też jest ratio legis kan. 220, taka jest myśl prawodawcy kościelnego. Ratio legis zaś ustawy kościelnej należy do samej normy ${ }^{84}$.

Problem polega jedynie na tym, czy podstawą prawną dla ochrony czci w aspekcie wewnętrznym jest część pierwsza czy też część druga kan. 220. Z wykładni językowej wynika, że zakres pojęcia bona fama obejmuje jedynie zakres zewnętrzny czci. Wykładnia systematyczna nie daje jasnej odpowiedzi. Wykładnia celowościowa tymczasem wskazuje na objęcie tym pojęciem także czci w jej aspekcie wewnętrznym. Z drugiej strony zaś dokumenty Magisterium Kościoła zawsze oddzielają od siebie cześć w znaczeniu wewnętrznym (szacunek, godność) i zewnętrznym (dobre imię, dobra sława), choć oba pojęcia zawsze występują obok siebie. Wydaje się też, że nie zawsze ochrona czci, godności człowieka przybiera wymiar intymności, jakkolwiek zakresy pojęciowe są nieostre. Stąd należy przyjać - mimo zastrzeżeń co do techniki legislacyjnej kan. 220 i dostatecznego oparcia w wykładni - że pod pojęciem bona fama należy rozumieć tak cześć w jej wymiarze zewnętrznym (dobre imię), jak i wewnętrznym (godność) ${ }^{85}$.

${ }^{83}$ Zob. A. B r z e m i a - B o n a r e k, Dopuszczalność dowodów..., s. 109, 129-130.

${ }^{84}$ Por. R. S o b a ń s k i, Idee przewodnie nowego Kodeksu Prawa Kanonicznego [w:] Duszpasterstwo w świetle nowego Kodeksu Prawa Kanonicznego, red. J. S y r y j c z y k, Warszawa 1985, s. 48, cytując P. H u i z i n g a .

${ }^{85}$ Tak też J. K r u k o w s k i, Prawa wiernych do dobrej opinii..., s. 231, pisząc jednak niezbyt ściśle o tym, że: „Przedmiotem tej ochrony jest prawo [podkr. moje - P.S.] do 'dobrej opinii', czyli honoru, szacunku i dobrego imienia, jakimi konkretny człowiek cieszy się w społeczeństwie w następstwie swego szlachetnego postępowania”. Podobnie w literaturze włoskiej; zob. L. C h i a p p e t t a, Il Codice..., s. 315, nb. 1375; G. D a 11 a To r r e [w:] Commento al Codice di Diritto Canonico, red. P. V. P i n t o, Città del Vaticana 2001, s. 127; L. S a b b a r e s e, I fedeli costituiti Popolo di Dio. Commento al Codice di Diritto Canonico libro II, parte I, Roma 2000, s. 44. Na marginesie tylko tych rozważań należy zauważyć, że użycie sformułowania prawo do dobrego imienia jest bardzo brzemienne w skutki. O jakie bowiem prawo tu chodzi? Jeżeli 


\section{Zakończenie}

Dobrze się stało, że ustawodawca kościelny nie pokusił się o definicję dobrego imienia. Zakres przedmiotowy normy, zawartej w części pierwszej kan. 220, musi się jednak spotkać z krytyką. Wydaje się bowiem, że pojęcie bona fama, stosując tylko interpretację literalną, obejmuje jedynie aspekt zewnętrzny czci (dobre imię, dobrą sławę), pomijając zaś jej aspekt wewnętrzny (godność osobistą). W rozwiązaniu tego problemu nie pomaga też wykładnia historyczna (analiza powstania kan. 220). Dlatego trzeba by przychylić się do wykładni rozszerzającej verba legis, znajdując pewne - co prawda słabe - podstawy do przyjęcia, że bona fama w kan. 220 oznacza cześć nie tylko w aspekcie zewnętrznym, ale i wewnętrznym.

Dlatego de lege ferenda w przepisie części pierwszej kan. 220 warto by było zastąpić dotychczasowe pojęcie bona fama nowym, obejmujaccym cześć, tak w jej aspekcie zewnętrznym, jak i wewnętrznym. Wydaje się, że pojęciem tym mogłaby być dignitas (godność) ${ }^{86}$.

o prawo podmiotowe, to chyba nie w znaczeniu cywilistycznym; por. J. C h a c i ń s k i, Prawa podmiotowe..., s. 139-143, 148-156, 163-170 (z cyt. tamże literaturą), a zwłaszcza s. 169; Z. R a d w a ń s k i, Prawo cywilne - część ogólna, Warszawa 1993, s. 122-123, nb. 354; A. S z p u n a r, Ochrona..., s. 96-103; w odniesieniu do prawa kanonicznego zob. R. S o b a ń s k i, Kościót jako podmiot prawa. Elementy eklezjologii prawnej, Warszawa 1983, s. 117-133. Jeżeli o prawo podmiotowe publiczne, to konstrukcja ta nie za bardzo wpisuje się w system prawa kanonicznego, w rzeczywistość Kościoła jako wspólnoty (communio); por. J. B o ć, A. B ł a ś [w:] Prawo administracyjne, red. J. B o ć, [Wrocław] Kolonia Limited 2000, s. 496-500; odnośnie do prawa kanonicznego negatywnie zob.: P. L o m b a r d í a, Die Grundrechte des Gläubigen, Internationale Zeitschrift für Theologie Concilium 5 (1969) nr 10, s. 610; R. S o b a ń s k i, Kościót jako podmiot pra$w a \ldots$, s. 126-127. Jeżeli zaś przyjąć instytucjonalną ochronę dobrego imienia, to nie należy w ogóle mówić o prawie (i tak też kwestia ta regulowana jest w szeregu ustawodawstw cywilnych); por. B. G a w li k, Ochrona dóbr osobistych. Sens $i$ nonsens tzw. praw podmiotowych osobistych, Zeszyty Naukowe Uniwersytetu Jagiellońskiego. Prace z wynalazczości i ochrony własności intelektualnej, z. 41, Kraków 1985; B. K o r d a s i e w i c z, Jednostka wobec środków masowego przekazu, Wrocław 1991; streszczenie poglądów: J. C h a c i ń s k i, Prawa podmiotowe..., s. 144-147 (z cyt. tamże literatura); Z. R a d w a ń s k i, Prawo cywilne - część ogólna, Warszawa 1993, s. 122-123, nb. 354. Ewentualnie można by posłużyć się konstrukcją specyficzną dla systemu prawa kanonicznego, a mianowicie mówiąc o kanonicznej ochronie podstawowego prawa chrześcijanina. Specyfika rozwiązania kanonicznego polegałaby na odesłaniu do teologii osoby w Kościele, chrztu, godności wiernego, a jednocześnie do tajemnicy Kościoła.

${ }^{86}$ Tak też proponował W. A y m a n s, „Munus” und „sacra potestas” [w:] Les Droits Fondamentaux du Chrétien dans l'Eglise et dans la Société. Actes du IV Congrès International de Droit Canonique, red. E. C o r e c c o, N. H e r z o g, A. S c o l a, Fribourg Suisse 1981, s. 200-201. Pojęcie to miałoby też oparcie na dokumentach Soboru Watykańskiego II, który dignitas używa, mówiąc o dignitas Episcoporum propria (CD 
W każdym razie kontekst życia Kościoła wymusi na teologach i kanonistach poważne przemyślenie zagadnienia ochrony dobrego imienia czy też czci każdego wiernego. Wystarczy zatrzymać się na problemach dziś szczególnie aktualnych, jak lustracja ludzi Kościoła w Polsce i w innych krajach postkomunistycznych. Zadanie, które czeka przed kanonistyką, jest i trudne, i złożone. Trzeba bowiem doprowadzić do ważenia równocennych wartości, np.: dobre imię duchownego, który był tajnym współpracownikiem komunistycznych służb specjalnych - prawo do prawdy i zadośćuczynienia - dobro Kościoła.

W każdym razie odkrycie konieczności ochrony dobrego imienia (godności) w praktyce Kościoła będzie dopiero zadaniem XXI wieku. Trzeba zatem za św. Leonem Wielkim papieżem wezwać w Kościele: Agnosce, o christiane, dignitatem tuam ${ }^{87}$

Der Begriff des guten Rufes (bona fama) im Codex des kanonischen Rechtes aus dem Jahre 1983 von Johannes Paul II. auf Grund von can. 220, erster Teil

Der Begriff des guten Rufes (bona fama) wird besonders im ersten Teil des can. 220 CIC behandelt. Aber auch die anderen Canones CIC (z.B. 378 § 1 n. 2, 483

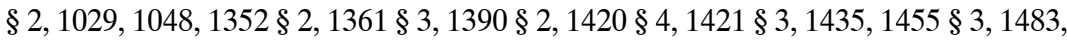
1548 § 2 n. 2, 1717 § 2 und 1741 n. 3, in sensu largo: 51, 699 § 1, 1611 n. 3, 1742 § 1, 1745; 700, $1727 \S 1 ; 697$ n. 2, 695 § 2, 1720 n. 2) betreffen auch den Schutz des guten Rufes. Die Worte, die in diesen Vorschriften verwendet werden, um den guten Ruf zu benennen, sind: bona fama, bona exsistimatio und infamia. Aus der Geschichte des can. 220 folgt, dass verba legis keine Bedeutung für die Auslegung des Begriffes des guten Rufes haben. Dagegen ist die Vorschrift des can. 220 der Rechtsgrundsatz, auf den sich alle den guten Ruf betreffenden Vorschriften des CIC beziehen. Nach der Durchführung einer Analyse der nichtkirchlichen Gesetzgebungen und bei extensiver Interpretation ist der Begriff bona fama im can. 220 so auszulegen, dass er "Würde" bedeutet, sowohl in ihrer äußeren (der gute Ruf), als auch in ihrer inneren (die Ehre) Dimension.

n. 25, 1); dignitas laicorum (LG n. 37, 3; PO n. 9, 2), nie wspominając już o dignitas humana w DH.

${ }^{87}$ Sermo 1 in Nativitate Domini, 1-3: PL 54, 193, cyt. za: Liturgia Horarum, t. I, Typis Polyglottis Vaticanis 1977, s. 328. W przekł. polskim: Poznaj swoja godność, chrześcijaninie! 